\title{
Religiousness is associated with lower levels of anxiety, but not depression, in medical and nursing students
}

\author{
(D) Jurema Ribeiro Luiz Gonçalves ${ }^{1}$ \\ Arthur Pereira Jorge \\ Guilherme Cia Zanetti ${ }^{3}$ \\ Elisângela de Assis Amaro ${ }^{1}$ \\ Ricardo Tonim Tótoli ${ }^{1}$ \\ Giancarlo Lucchetti ${ }^{2}$
}

1. Federal University of Triangulo Mineiro - UFTM, Uberaba, MG, Brasil 2. Federal University of Juiz de Fora - UFJF, Juiz de Fora, MG Brasil 3. Hospital Israelita Albert Einstein, São Paulo, SP, Brasil

http://dx.doi.org/10.1590/1806-9282.64.06.537

\section{SUMMARY}

OBJECTIVES: To evaluate the association between religious and spiritual beliefs, anxiety and depression in medical and nursing students. METHODS: A cross-sectional study was carried out with medical and nursing students from a Brazilian university. Students were randomly selected and filled out a questionnaire that contained sociodemographic, religious (Duke Religion Index), spirituality (Self-spirituality rating scale) and mental health - depression and anxiety (Hospital Anxiety and Depression Scale) data. Linear regression models were used to evaluate the association of $R / E$ with mental health, with adjustments for sociodemographic variables.

RESULTS: A total of 187 students (90.7\%) were included in the study, 56.1\% female, an average of 23 years old, and $69 \%$ were enrolled in the medical program. Of the students, $29.4 \%$ attended religious services once a week or more often, $10.7 \%$ had private religious activities once a day or more often, and the indexes of intrinsic religiosity and spirituality were moderate. In the linear regression, adjusted for sociodemographic variables, the religious attendance was the only factor associated with lower levels of anxiety (Beta: -0.178, $p=0.026$ ). The other dimensions of religiousness or spirituality were not associated with levels of anxiety and depression.

CONCLUSIONS: The present study showed that only the religious attendance was associated with the mental health of the medical and nursing students. These results demonstrate that some students use religious support in an attempt to minimize the negative effects of their university life. This support seems to be more effective when it involves participation in religious social activities in relation to private activities.

KEYWORDS: Anxiety. Religion and Medicine. Students, Medical. Students, Nursing. Spirituality.

\section{INTRODUCTION}

Starting university has an impact on people's lives, who are suddenly faced with new responsibilities that require a change in their habits, which may cause emotional conflicts'. Among the undergraduate programs, those in the health area are usually very demanding and their strenuous routine can be considered a stressful situation that can have a negative impact on student's well-being ${ }^{3,4}$.

The adversity caused by academic difficulties, in addition to personal e social problems, may lead to emotional disorders. A systematic review including 40 studies showed that $13 \%$ to $25 \%$ of medical students suffer from depression and around 34\% presented anxiety scores, evidencing a significant prevalence of these symptoms 5 .

Faced with this, students may feel the need to develop coping mechanisms to deal with this new context of life ${ }^{6}$. Religiousness and spirituality are currently seen as strategies capable of providing an increased

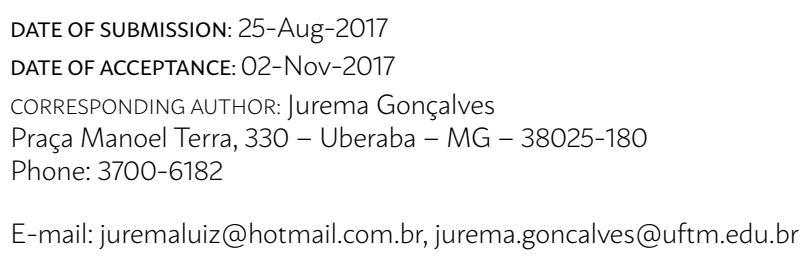

arthur_pj@hotmail.com ciagz@hotmail.com li282004@yahoo.com.br rttotoli@gmail.com g.lucchetti@yahoo.com.br, gian.tln@terra.com.br 
sense of purpose in life, well-being, and personal satisfaction, which are all associated with higher resistance to stressful situations ${ }^{7-9}$. Religiousness and spirituality are often used as synonyms. However, there is a growing distinction between these terms ${ }^{1,2}$. Religiousness is characterized by the experience of an organized system of beliefs and symbols shared between a group of people and presenting special behavioral, social, and doctrinal characteristics. It can be understood as organizational, non-organizational and intrinsic ${ }^{10}$. Spirituality is the personal search for answers and meaning to existential matters, involving the understanding of the purposes of life and its possible connections with transcendence ${ }^{11}$.

Religiousness is being increasingly studied nowadays $^{12-15}$.

In a systematic review conducted between 2003 and 2013, it was evidenced that most studies pointed out that spiritual/religious activities play a protective role in mental health and the prevalence of minor psychiatric disorders (anxiety and depression) ${ }^{16}$. By means of spirituality, religiousness, or both, people can positively associate mental and physical well-being dimensions, thus experiencing a sense of shelter when faced with adversity ${ }^{17}$. It is also known that both spirituality and religiousness influence stress reduction and are therefore considered protective factors for depression and anxiety disorders ${ }^{18,19}$.

Despite the evidence, there are still few studies that have assessed how religious beliefs influence the mental health of medical students and their results are conflicting, ${ }^{9,20,21}$.

This way, this study aims to evaluate the connection between spiritual/religious beliefs, anxiety, and depression in medical and nursing students.

\section{METHODOLOGY}

This is a cross-sectional observational study with a quantitative approach conducted in the Federal University of the Triângulo Mineiro (UFTM), in Uberaba, Minas Gerais, Brazil, during November and December of 2015. It was authorized by the Research Ethics Committee of the Federal University of the Triângulo Mineiro by decision No 1.235.044, and the students signed an informed consent form in order to participate.

UFTM is a Brazilian public university that has approximately 5,000 students and programs on several knowledge areas, including in health. The medical
(486 students enrolled) and nursing (271 students enrolled) programs have a student-focused traditional curriculum.

For this study, we included students enrolled in the medical and nursing programs that were 18 years old or older, both male and female, who voluntarily accepted to be included. According to a previous sample calculation, we needed 206 students, who were randomly drawn using a list with the names of all students. The students were then approached in person by previously trained research collaborators, before or after classes, in pre-established moments, when they were informed of the purpose of the study.

The questionnaire was self-filling, took 15 minutes and was composed of:

- Sociodemographic variables: age, gender, ethnicity and family income.

- Religiousness: by means of the Duke Religion Index (Durel). It is a brief multidimensional measurement that uses 5 items to measure three dimensions of religious involvement: organizational (ORA) - attendance at religious meetings, such as study groups, cults, and masses; non-organizational (NORA) - frequency at private religious activities, such as prayer, meditation, and reading of religious texts; and intrinsic religiousness (IR) - Search for internalization and complete religious experience as the individual's main objective. Immediate ends are considered secondary and achieved in harmony with basic religious principles. The scale is authored by Koenig et al. (2001) and has been validated in Portuguese ${ }^{22}$.

- Spirituality: using the Spirituality Self Rating Scale (SSRS), which consists of a scale that assesses aspects of spirituality with items that focus on the individual spiritual orientation, whether the individual considers spiritual matters important or not, and how this applies to their lives. It is a self-filling instrument composed of six items. The original scale was developed by Galanter at al. and was validated into Portuguese $^{23}$.

- Hospital Anxiety and Depression Scale (HADS): is a scale that consists of two subscales with 14 multiple choice questions, 7 for anxiety and 7 for depression. The overall score in each subscale ranges from 0 to 21 . The scale was developed by Zigmond and Snaith in 1983 and validated into Portuguese ${ }^{24}$. Despite having been 
initially created for non-psychiatric hospitalized patients, it has been currently used in literature for several other populations, including medical students ${ }^{25}$.

The sample size calculation corresponded to the proportional number of each program, considering an additional $25 \%$ of losses. It considered a determination coefficient $\mathrm{R}^{2}=0.10$ in a multiple linear regression model with five predictors $(\mathrm{R} / \mathrm{E}$ variable and sociodemographic), with type I error or significance level Alfa $=0.05$, and type II 0,10, thus resulting in a priori statistical power of $90 \%$. The sample was made up of 206 students total, 131 from the medical program, and 75 from the nursing program. The students selected were contacted, and those who agreed to participate individually filled out the printed questionnaires on a date and time arranged between them and the researcher in charge.
The data consistency was performed by double-entry typing on an Excel sheet. Next, they were exported to the SPSS (Statistical Package for the Social Science) application, version 20.0, for conducting the statistical analysis. The data was analyzed by descriptive techniques, frequency distribution, mean and standard deviation.

The inferential analysis used the Student's t-test for comparing anxiety scores and the categorical variables (program and gender). Then, linear regression models were performed with the HADS scores for depression and anxiety as dependent variables; $\mathrm{R} / \mathrm{E}$ measures were added individually and adjusted for sociodemographic variables (gender, age, ethnicity and family income). We chose not to group all the religiousness and spirituality variables into a single model due to the high correlation between them (above $r=0.60$ ), which would increase multi-

TABLE 1 - PERCENTAGE DISTRIBUTION ON RELIGIOUSNESS OF MEDICAL AND NURSING STUDENTS FROM A UNIVERSITY IN THE MUNICIPALITY OF UBERABA/MG, 2015.

\begin{tabular}{|c|c|c|c|}
\hline Variables & & $\mathrm{N}$ & $\%$ \\
\hline Religion & $\begin{array}{l}\text { Catholic } \\
\text { Protestant } \\
\text { Adventist } \\
\text { Evangelical } \\
\text { Spiritualist } \\
\text { Others } \\
\text { Unfilled }\end{array}$ & $\begin{array}{l}68 \\
7 \\
3 \\
13 \\
29 \\
3 \\
64 \\
\end{array}$ & $\begin{array}{l}36.7 \\
3.7 \\
1.6 \\
7 \\
15.5 \\
1.6 \\
34\end{array}$ \\
\hline $\begin{array}{l}\text { How often do you attend church or other religious } \\
\text { meetings? }\end{array}$ & $\begin{array}{l}\text { More than once a week } \\
\text { Once a week } \\
\text { Two or three times per month } \\
\text { A couple of times a year } \\
\text { Once a year or less } \\
\text { Never }\end{array}$ & $\begin{array}{l}15 \\
37 \\
27 \\
44 \\
35 \\
29\end{array}$ & $\begin{array}{l}8.2 \\
19.7 \\
14.4 \\
23.5 \\
18.7 \\
15.5\end{array}$ \\
\hline $\begin{array}{l}\text { How often do you dedicate your time to individual } \\
\text { religious activities such as prayer, meditation, read- } \\
\text { ing the Bible or other religious texts? }\end{array}$ & $\begin{array}{l}\text { More than once a day } \\
\text { Daily } \\
\text { Two a week or more } \\
\text { Once a week } \\
\text { A few times per month } \\
\text { Rarely or never }\end{array}$ & $\begin{array}{l}12 \\
63 \\
23 \\
20 \\
25 \\
44\end{array}$ & $\begin{array}{l}6.4 \\
33.7 \\
12.3 \\
10.7 \\
13.4 \\
23.5\end{array}$ \\
\hline $\begin{array}{l}\text { I feel the presence of God (or the Holy Spirit) in } \\
\text { my life. }\end{array}$ & $\begin{array}{l}\text { Completely true for me } \\
\text { Mostly true } \\
\text { I am not sure } \\
\text { Mostly not true } \\
\text { Not true }\end{array}$ & $\begin{array}{l}85 \\
53 \\
23 \\
7 \\
19\end{array}$ & $\begin{array}{l}45.4 \\
28.3 \\
12.3 \\
3.7 \\
10.2\end{array}$ \\
\hline $\begin{array}{l}\text { My religious beliefs are the foundation of my } \\
\text { entire way of living. }\end{array}$ & $\begin{array}{l}\text { Completely true for me } \\
\text { Mostly true } \\
\text { I am not sure } \\
\text { Mostly not true } \\
\text { Not true }\end{array}$ & $\begin{array}{l}27 \\
63 \\
31 \\
26 \\
40\end{array}$ & $\begin{array}{l}14.4 \\
33.7 \\
16.6 \\
13.9 \\
21.4\end{array}$ \\
\hline $\begin{array}{l}\text { I make a real effort to put my religion into practice } \\
\text { in all aspects of my life. }\end{array}$ & $\begin{array}{l}\text { Completely true for me } \\
\text { Mostly true } \\
\text { I am not sure } \\
\text { Mostly not true } \\
\text { Not true }\end{array}$ & $\begin{array}{l}24 \\
56 \\
32 \\
31 \\
44\end{array}$ & $\begin{array}{l}12.8 \\
29.9 \\
17.2 \\
16.6 \\
23.5\end{array}$ \\
\hline
\end{tabular}

Source: Prepared by the authors. 
collinearity. A p $<0.05$ was determined as significant and Beta values were described, as well as the proportion of variance in the dependent variable in relation to the predictor variables (R-square).

\section{RESULTS}

In the sample of 206 students, 187 (90.7\%) agreed to participate in the research. Of these, $69 \%$ were medical students and $31 \%$ nursing students, most of them between 18 and 44 years old, with an average age of 23 . As for gender, $56.1 \%$ were females and $43.9 \%$ males; $67.9 \%$ declared themselves to be white. When questioned about religion, $27.9 \%$ said to attend religious services once a week or more often, $40.1 \%$ engaged in private religious practices once a day or more often, and $34.8 \%$ declared not having any religion (Table 1).

The scores from the anxiety and depression questionnaire were bivariate compared by means of the Student's t-test regarding program, gender, and ethnicity (Table 2) For male individuals, the mean anxiety was 7.36 (DP: 3.89), in females it was 8.57 (SD: 3,99 ), with statistical relevance in the comparison between them. When comparing anxiety scores and program, no statistical relevance was found (Table 2).

None of the religiousness and spirituality variables were associated with the levels of depression in the sample studied, in both adjusted and non-adjusted models. Regarding anxiety, only organizational religiosity (religious attendance) was associated with lower levels of anxiety (Beta=-0.178, $p=0.026$ ) in the adjusted model. Despite the statistical significance, the proportion of variance in the dependent variable in relation to the predictor variables (R-square) was low (R-square $=0.005$ ) for the model without adjustment and (R-square=0.065) for the adjusted model (Table 3).

\section{DISCUSSION}

The present study showed that medical and nursing students have religious and spiritual beliefs, and that only religious attendance was associated with fewer anxiety symptoms, but the same did not apply to depression. These data highlight the fact that even among young people with high levels of education

TABLE 2 - COMPARISON OF ANXIETY AND DEPRESSION SCORES BY PROGRAM, GENDER, AND ETHNICITY OF THE MEDICAL AND NURSING STUDENTS FROM A UNIVERSITY IN THE MUNICIPALITY OF UBERABA/MG, 2015.

\begin{tabular}{|c|c|c|c|c|c|c|}
\hline & $\begin{array}{l}\text { Mean } \\
\text { anxiety }\end{array}$ & $\begin{array}{l}\text { Anxiety } \\
\text { standard } \\
\text { deviation }\end{array}$ & Anxiety P & $\begin{array}{l}\text { Mean } \\
\text { depression }\end{array}$ & $\begin{array}{l}\text { Depression } \\
\text { standard } \\
\text { deviation }\end{array}$ & $\begin{array}{l}\text { Depression } \\
\text { P }\end{array}$ \\
\hline $\begin{array}{l}\text { Program } \\
\text { Medicine } \\
\text { Nursing }\end{array}$ & $\begin{array}{l}8.04 \\
8.03\end{array}$ & $\begin{array}{l}4.01 \\
3.94\end{array}$ & 0.98 & $\begin{array}{l}5.44 \\
4.93\end{array}$ & $\begin{array}{l}3.28 \\
2.82\end{array}$ & 0.305 \\
\hline $\begin{array}{l}\text { Gender } \\
\text { Female } \\
\text { Men }\end{array}$ & $\begin{array}{l}8.57 \\
7.36\end{array}$ & $\begin{array}{l}3.99 \\
3.89\end{array}$ & 0.04 & $\begin{array}{l}5.68 \\
4.77\end{array}$ & $\begin{array}{l}3.09 \\
3.15\end{array}$ & 0.047 \\
\hline
\end{tabular}

Source: Prepared by the authors.(Student's t-test, $p \leq 0.05$ )

TABLE 3 - LINEAR REGRESSION ASSESSING THE FACTORS ASSOCIATED WITH ANXIETY AND DEPRESSION IN MEDICAL AND NURSING STUDENTS FROM A UNIVERSITY IN THE CITY OF UBERABA/MG, 2015

\begin{tabular}{|c|c|c|c|c|c|c|c|c|}
\hline & \multicolumn{4}{|c|}{ Non-adjusted regression } & \multicolumn{4}{|c|}{$\begin{array}{l}\text { Regression adjusted for sociodemographic character- } \\
\text { istics }\end{array}$} \\
\hline & $B(S E)$ & Beta & $\mathrm{p}$ & $\begin{array}{l}\text { Model } \\
\text { R-square }\end{array}$ & $B(S E)$ & Beta & $\mathrm{p}$ & $\begin{array}{l}\text { Model } \\
\text { R-square }\end{array}$ \\
\hline $\begin{array}{l}\text { Depression } \\
\text { Spirituality } \\
\text { ORA } \\
\text { NORA } \\
\text { IR }\end{array}$ & $\begin{array}{l}-0.017(0.036) \\
-0.052(0.149) \\
-0.050(0.133) \\
-0.028(0.063)\end{array}$ & $\begin{array}{l}-0.036 \\
-0.025 \\
-0.027 \\
-0.033 \\
\end{array}$ & $\begin{array}{l}0.629 \\
0.730 \\
0.710 \\
0.653 \\
\end{array}$ & $\begin{array}{l}0.001 \\
0.001 \\
0.001 \\
0.001 \\
\end{array}$ & $\begin{array}{l}-0.012(0.038) \\
-0.217(0.162) \\
-0.036(0.138) \\
-0.029(0.068)\end{array}$ & $\begin{array}{l}-0.025 \\
-0.107 \\
-0.020 \\
-0.033\end{array}$ & $\begin{array}{l}0.750 \\
0.181 \\
0.791 \\
0.673 \\
\end{array}$ & $\begin{array}{l}0.054 \\
0.063 \\
0.054 \\
0.055 \\
\end{array}$ \\
\hline $\begin{array}{l}\text { Anxiety } \\
\text { Spirituality } \\
\text { ORA } \\
\text { NORA } \\
\text { IR }\end{array}$ & $\begin{array}{l}-0.004(0.045) \\
-0.173(0.189) \\
0.025(0.169) \\
0.049(0.080)\end{array}$ & $\begin{array}{l}-0.006 \\
-0.067 \\
0.011 \\
0.045\end{array}$ & $\begin{array}{l}0.937 \\
0.360 \\
0.882 \\
0.545\end{array}$ & $\begin{array}{l}0.001 \\
0.005 \\
0.001 \\
0.002\end{array}$ & $\begin{array}{l}-0.046(0.048) \\
-0.459(0.205) \\
-0.120(0.175) \\
0.039(0.087)\end{array}$ & $\begin{array}{l}-0.075 \\
-0.178 \\
-0.052 \\
0.036\end{array}$ & $\begin{array}{l}0.340 \\
0.026 \\
0.496 \\
0.654\end{array}$ & $\begin{array}{l}0.044 \\
0.065 \\
0.041 \\
0.040\end{array}$ \\
\hline
\end{tabular}

${ }^{*} p<0.05{ }^{* \star} p<0.01{ }^{* \star *} p<0.001$ Model 1: gender, age, ethnicity, income. 
religious beliefs are still used as a possible coping mechanism for adverse situations.

Comparing our findings with those of other institutions, they are similar to those of Lupo and Strous ${ }^{21}$, who found that religiousness was associated to lower levels of anxiety symptoms in Israeli medical students, and of Vasegh and Mohammadi ${ }^{20}$, who verified that religious belief was associated to less anxiety in Iranian medical students. However, our findings differ from those of another study that found a connection between religiousness and depression, but not anxiety, in Brazilian medical students 9

These sometimes discordant results can be justified by a number of factors. Religious affiliation and culture can change depending on the type of sample studied; institutions can also have different curriculum and offer different types of psychological support; and religiousness can often have a more negative (religious suffering) or positive nature. In a recent systematic review, Koenig ${ }^{26}$ evaluated 299 studies and found that 147 of them (49\%) showed an inverse association between $\mathrm{R} / \mathrm{E}$ and anxiety (a result compatible with our findings), while 127 found no connection, and 33 showed a positive association. The same results were found for depression. The author found that of the 444 studies examining the connection between R/E and depression, 272 (61\%) indicated an inverse association, 144 found no connection, and 28 found a positive association.

In the same way that the association between $\mathrm{R} / \mathrm{E}$ and anxiety can vary among studies, the religiousness measurements considered (ORA, NORA, IR) also present variance in the literature. In a study by Luchetti et al. that assessed the presence of anxiety in nurses that worked in home care, it was found that those who presented higher anxiety levels were the ones with lower ORA and higher NORA. In another study conducted with adults in a Malaysian community, it was found that IR and NORA behaved as possible risk factors for anxiety ${ }^{28}$. Religiousness as a risk factor was also demonstrated by Mohamad et $\mathrm{a}^{29}$.

From the studies presented, we can infer that the religious measurements can sometimes behave as risk factors, and other times as protective factors, under different situations and varying according to the context and population. According to Moutinho et $\mathrm{al}^{9}$, it is important to have studies that assess mental health and its relationship with religiousness in different groups, such as university students, aiming at the early identification of risks and a greater understanding of the relationship between religiousness and adversity. This can lead to the development of prevention and coping mechanisms specific to each population.

Finally, our findings reinforce the premise that students use their beliefs as a way of dealing with adversity, which is corroborated by other studies with different populations in which religion offers a coping mechanism for stressful stuations ${ }^{7,8}$, such as disease-related vulnerability ${ }^{30}$, the emotional impact felt when faced with the brevity of life ${ }^{31}$, and the difficulties inherent to health care ${ }^{32}$. Educators must be aware of the students' needs and of how religiousness and spirituality are used (functionally or dysfunctionally).

As limitations of the study, we can mention the use of two health care courses, since nowadays there is a tendency to have multidisciplinary teams in health care. Additionally, there is the fact that a cross-sectional approach was used, when a longitudinal follow-up could clarify possible variations in the relationship between spirituality, religiousness and anxiety throughout the program. Finally, the students' social support was not evaluated. Religious attendance can lead to a greater social support, which can be a mechanism for better mental health.

\section{CONCLUSION}

The present study showed that only the religious attendance was associated with the mental health of medical and nursing students, who used the religious practice to minimize the negative impacts of university life. This support seems to be more effective when it involves the participation in social religious activities over private activities.

In the academic environment, the possible impact of religiousness on anxiety levels requires new studies focused on understanding the perception of students regarding these themes for a broader understanding of their relationships. In addition, in the healthcare perspective, the importance of belief when faced with sickness has been increasingly acknowledged, which highlights the importance given to spirituality and religiousness by patients, family members and staff. In this way, it is necessary that future professionals be fully prepared in order to have the required sensitivity to fully exercise the abilities learned at the university as a perception tool, knowing how to deal with the spirituality and religiousness of each individual. 


\section{RESUMO}

OBJETIVO: Avaliar a associação entre crenças religiosas/espirituais, ansiedade e depressão em estudantes dos cursos de medicina e enfermagem.

MÉTODOS: Estudo transversal realizado com estudantes de medicina e enfermagem de uma universidade brasileira. Estudantes foram sorteados de forma aleatória e preencheram um questionário que continha dados sociodemográficos, de religiosidade (Duke Religion Index), espiritualidade (Self-spirituality rating scale) e saúde mental - depressão e ansiedade (Hospital Anxietyand Depression Scale). Foram usados modelos de regressão linear para avaliar a associação de R/E com saúde mental ajustando para as variáveis sociodemográficas.

RESULTADOS: Um total de 187 estudantes abordados (90,7\%) foi incluído no estudo, sendo 56,1\% do sexo feminino, média de 23 anos de idade e 69\% fazendo parte do curso de medicina. Dos estudantes, 29,4\% frequentavam serviços religiosos uma vez ou mais por semana, 10,7\% realizavam atividades privadas religiosas uma ou mais vezes ao dia e os índices de religiosidade intrínseca e espiritualidade foram moderados. Na regressão linear, ajustada para variáveis sociodemográficas, a frequência religiosa foi a única que esteve associada a menores níveis de ansiedade (Beta: -0,178, $p=0,026$ ). As demais dimensões de religiosidade ou espiritualidade não estiveram associadas a níveis de ansiedade e depressão.

CONCLUSÕES: O presente estudo evidenciou que apenas a frequência religiosa esteve associada à saúde mental do estudante de medicina e enfermagem. Esses resultados demonstram que alguns estudantes utilizam suporte religioso na tentativa de minimizar os efeitos negativos de sua vida universitária. Esse suporte parece ser mais efetivo quando envolve a participação em atividades sociais religiosas em relação a atividades privadas.

PALAVRAS-CHAVE: Ansiedade. Religião e medicina. Estudantes de medicina. Estudantes de enfermagem. Espiritualidade.

\section{REFERENCES}

1. Chaves EC, lunes HD, Moura CC, Carvalho CL, Silva AM, Carvalho EC Anxiety and spirituality in university students: a cross-sectional study. Rev Bras Enferm. 2015;68(3):444-9, 504-9.

2. Chaves FS. Religião, religiosidade ou espiritualidade? A importância da definição dos termos no contexto de saúde física e psíquica. Humanas Sociais \& Aplicadas. 2015;5(14):64

3. Fares J, Al Tabosh H, Saaededdin Z, El Mouhayyar C, Aridi H. Stress, burnout and coping strategies in preclinical medical students. N Am J Med Sci. 2016;8(2):75-81.

4. Kleiveland B, Natvig GK, lepsen R. Stress, sense of coherence and quality of life among Norwegian nurse students after a period of clinical practice. Peer). 2015;3:e1286.

5. Dyrbye LN, Thomas RM, Shanafelt TD. Systematic review of depression, anxiety, and other indicators of psychological distress among US and $\mathrm{Ca}$ nadian medical students. Acad Med. 2006;81(4):354-73.

6. Saoji AA. Yoga: a strategy to cope up stress and enhance wellbeing among medical students. N Am J Med Sci. 2016;8(4):200-2.

7. Krägeloh CU, Henning MA, Billington R, Hawken SI. The relationship between quality of life and spirituality, religiousness, and personal beliefs of medical students. Acad Psychiatry. 2015;39(1):85-9.

8. Krok D. Religiousness, spirituality, and coping with stress among late adolescents: a meaning-making perspective. J Adolesc. 2015;45:196-203.

9. Moutinho IL, Maddalena NC, Ronald RK, Lucchetti AL, Tibiriçá $\mathrm{SH}$, Ezequiel OD, et al. Depression, stress and anxiety in medical students: a cross-sectional comparison between students from different semesters. Rev Assoc Med Bras (1992). 2017;63(1):21-8.

10. Koenig HG, Büssing $A$. The Duke University Religion Index (DUREL): a five-item measure for use in epidemiological studies. Religions. 2010;1(1):78-85.

11. Weathers E, McCarthy G, Coffey A. Concept analysis of spirituality: an evolutionary approach. Nurs Forum. 2016;51(2):79-96.

12. Ivtzan I, Chan CP, Gardner HE, Prashar K. Linking religion and spirituality with psychological well-being: examining self-actualization, meaning in life, and personal growth initiative. J Relig Health. 2013;52(3):915-29.

13. Park NS, Lee BS, Sun F, Klemmack DL, Roff LL, Koenig HG. Typologies of religiousness/spirituality: implications for health and well-being. Relig Health. 2013;52(3):828-39.

14. Tuck I, Anderson L. Forgiveness, flourishing, and resilience: the influences of expressions of spirituality on mental health recovery. Issues Ment Health Nurs. 2014;35(4):277-82.

15. Lucchetti G, Lucchetti AL. Spirituality, religion, and health: over the last 15 years of field research (1999-2013). Int J Psychiatry Med. 2014;48(3):199-215.

16. Carlotto RC. Espiritualidade e sintomatologia depressiva em estudantes universitários brasileiros. Rev Psicol UNESP. 2013;12(2):50-60.

17. Valcanti CC, Chaves ECL, Mesquita AC, Nogueira DA, Carvalho EC. Cop- ing religioso/espiritual em pessoas com doença renal crônica em tratamento hemodialítico. Rev Esc Enferm USP. 2012;46(4):838-45.

18. Volcan SMA, Sousa PLR, Mari JJ, Horta BL. Relação entre bem-estar espiritual e transtornos psiquiátricos menores: estudo transversal. Rev Saúde Pública. 2003;37(4):440-5.

19. Moreira-Almeida A, Koenig HG, Lucchetti G. Clinical implications of spirituality to mental health: review of evidence and practical guidelines. Rev Bras Psiquiatr. 2014;36(2):176-82

20. Vasegh S, Mohammadi MR. Religiosity, anxiety, and depression among a sample of Iranian medical students. Int J Psychiatry Med. 2007;37(2):213-27.

21. Lupo MK, Strous RD. Religiosity, anxiety and depression among Israeli medical students. Isr Med Assoc J. 2011;13(10):613-8.

22. Lucchetti G, Granero Lucchetti AL, Peres MF, Leão FC, Moreira-Almeida A, Koenig HG. Validation of the Duke Religion Index: DUREL (Portuguese version). J Relig Health. 2012 Jun;51(2):57986. doi: 10.1007/s10943-010-9429-5

23. Gonçalves AMS, Pillon SC. Adaptação transcultural e avaliação da consistência interna da versão em português da Spirituality Self Rating Scale (SSRS), Rev Psiquiatr Clín. 2009;36(1):10-5.

24. Castro MMC. Validade da escala hospitalar de ansiedade e depressão em pacientes com dor crônica. Rev Bras Anestesiol. 2006;56(5):470-7.

25. Vasconcelos TC, Dias BRT, Andrade LR, Melo GF, Barbosa L, Souza E. Prevalência de sintomas de ansiedade e depressão em estudantes de Medicina. Rev Bras Educ Méd. 2015;39(1):135-42.

26. Koenig HG. Religion, spirituality, and health: the research and clinical implications. ISRN Psychiatry. 2012;2012:278730.

27. Lucchetti G, Lucchetti AL, Oliveira GR, Crispim D, Pires SL, Gorzoni $\mathrm{ML}$, et al. Nursing home care: exploring the role of religiousness in the mental health, quality of life and stress of formal caregivers. J Psychiatr Ment Health Nurs. 2014;21(5):403-13.

28. Kader Maideen SF, Mohd Sidik S, Rampal L, Mukhtar F. Prevalence, associated factors and predictors of anxiety: a community survey in Selangor, Malaysia. BMC Psychiatry. 2015;15:262.

29. Mohamad AS, Draman S, Aris M, Musa R, Malik M. Depression, anxiety, and stress among adolescents in Kuantan and its association with religiosity: a pilot study. In: $2^{\text {nd }}$ World Congress on Integration Islamicisation: Focus On Medical \& Health Care Sciences 2016 (2WCII-2016), 21st-23rd October 2016, Kuantan, Pahang.

30. Rocha ACAL, Ciosak SI. Doença crônica no idoso: espiritualidade e enfrentamento. Rev Esc Enferm USP 2014; 48(Esp2):92-8.

31. Garanito MP, Cury MRG. A espiritualidade na prática pediátrica. Rev Bioét. 2016;24(1):49-53.

32. Fonseca MSM, Bueno ME, Schliemann AL, Kitanishi NY, Floriam Junior LC. Espiritualidade e estudantes de medicina: contribuições para o ensino médico. Rev Fac Ciênc Méd Sorocaba. 2014;16(2):55-8. 